\title{
BARRIERS IN ENHANCEMENT OF LOGISTICS IN THE REPUBLIC OF UZBEKISTAN
}

\author{
Tulaganova Shirin, \\ junior student of SOL at Inha University in Tashkent, Uzbekistan
}

DOI: https://doi.org/10.31435/rsglobal_ejits/31072019/6577

\section{ARTICLE INFO}

Received 15 May 2019

Accepted 22 July 2019

Published 31 July 2019

\section{KEYWORDS}

Logistics;

US Agency for International

Development(USAID);

German Society for International

Cooperation(GIZ);

International Road

Transport(IRT);

Logistics Performance

Index(LPI).

\begin{abstract}
It's hard to imagine any country which operates well organized foreign trade without logistics opportunities. Either an experienced entrepreneur or a startup owner in business field, they both have to provide quality services at as a low cost as possible. Because Logistics means, first of all, customer satisfaction. Clients should be informed 24/7 a day about the status of their order. Uzbekistan is twice closed, that is, one of the two countries in the world that have access to the ocean through the territory of two neighboring countries. The most important factor of the attractive geostrategic position of Uzbekistan is the availability of a developed system of transport communications, which practically satisfies the internal transportation needs. The Republic has the highest density of networks of railways and highways in Central Asia. Nevertheless, logistics services are relatively hard and expensive since Uzbekistan has no access to the sea and is far removed from the dominating global markets.
\end{abstract}

Citation: Tulaganova Shirin. (2019) Barriers in enhancement of Logistics in the Republic of Uzbekistan. European Journal of Intelligent Transportation Systems. 1(2). doi: 10.31435/rsglobal_ejits/31072019/6577.

Copyright: (c) 2019 Tulaganova Shirin. This is an open-access article distributed under the terms of the Creative Commons Attribution License (CC BY). The use, distribution or reproduction in other forums is permitted, provided the original author(s) or licensor are credited and that the original publication in this journal is cited, in accordance with accepted academic practice. No use, distribution or reproduction is permitted which does not comply with these terms.

Introduction. There are obstacles towards integration of logistics systems in Uzbekistan. Below we will view some of them.

Any independent country has its own legislative system related to industry, business, economy and other aspects in order to protect people working in these areas. This issue was discussed at a regional forum in Almaty organized by the US Agency for International Development(USAID) and the German Society for International Cooperation(GIZ) in 2017. In general, the Central Asian countries, including Uzbekistan, have developed a solid legislative framework in the field of land transport. A number of by-laws and various state development programs regulating international road transport(IRT) of goods have been adopted. However, all countries are characterized by inadequate legislative regulation, lack of clear requirements for a mechanism for managing cargo flows. For instance, as was mentioned in the forum, in the sphere of regulation, the countries of Central Asia carry out rail transportation on the basis of the Agreement on International Goods Rail Transport.

Research and methodology. However, there are a number of weak points:

- the end-to-end transport bill is rarely used and door-to-door service is not sufficiently developed;

- the rules of maintenance and registration are not harmonized, because of which large downtime is observed.

In 12 December, 2017 The Chamber of Commerce and Industry of Uzbekistan held a meeting of the Expert Council on Transport and Logistics. Participants discussed the development of road transport in Uzbekistan. At the meeting, problems and barriers that adversely affected the development of this sphere were voiced:

- the sphere of cargo transportation by motor transport are not transparent in tax and insurance terms 
- the current state of the monetary, tax and customs-excise policy does not allow for an active modernization of the rolling stock of national and international carriers.

Transportation, as one of the main parts of Logistics, plays an enormous role in enhancing growth rate of domestic economy. The share of rail transport in Uzbekistan accounts for more than $65 \%$ of the volume of freight turnover of all types of transport. In road transport, the share of freight turnover is $33.7 \%$ of all modes of transport. The existing network of railway and automobile transport communications not only reliably connects the most remote regions of the republic, provides access to international transport systems, but also provides broad access to the main sources of natural and mineral resources of the country. The Chamber of Commerce and Industry of Uzbekistan also pointed out some issues connected to transportation of the country:

- the pace of renewal of the rolling stock seriously lags behind the dynamics of economic growth;

- one third of the truck fleet consists of morally and physically obsolete vehicles with high production costs and specific consumption for fuel and lubricants;

- the speed of traffic along the roads of Uzbekistan is 2 times less than in the EU.

Moreover, not only law and transportation obstacles existed. The lack of modern means of technical control - scanners for checking cars in laden condition, and not all border crossing points are equipped with weighing scales for trucks. In addition, strategies for the development of logistics centers, terminals for storage of transport infrastructure are not enough, in part a shortage of specialists in the design and creation of logistics centers, implementation and development managers to provide a wide range of transport and logistics services. Next, there is no information portal on the provision of reliable and timely data on logistics services, free storage space, storage conditions, tariffs and the cost of storage and handling services, that is, all the information that makes trade transparent and predictable. In 2015 Association for the Development of Business Logistics made a research of state of logistics in Uzbekistan. According to the results of the survey, only $18 \%$ out of the total number of transport companies are available to provide additional services except for the carriage itself. Problems in the logistics field serve as barrier to the fast development of others such as e-commerce, trade with developed countries of Europe/USA, and obviously the economic state of the country.

Analysis and results. For solving all the problems given above, a number of laws and measures are taken to improve transport and logistics services. The tasks of developing transport communications, increasing the volume of transportation and competitiveness depend on the implementation of a whole range of measures - from technical equipment to the training of qualified personnel, from the improvement of technology to the introduction of information and logistics systems of work organization. Recent years, the republic has paid much attention to the improvement of transport infrastructure, including the creation of large logistics centers for the organization of a rational process of transporting goods and services from producers to consumers, not only between the regions of the republic, but also on an international scale. Logistic centers in Angren and Navoi can be examples of this. The Republic of Uzbekistan plans to build 17 logistics centers specializing in processing, storage and transportation of fruit and vegetable products by the year of 2020. And construction of one of them has already began. The center, organized by Greenfoodtrade LLC in the Yukorichirchik district of the Tashkent region, is engaged in storing, processing and exporting agricultural products. In a complex of more than 40 hectares, five cross-docking; a hypermarket; a warehouse for sorting and storing agricultural products; a refrigerator with a capacity of 10,000 tons and a hotel for 150 people will be built. The project will be launched at full capacity in the third quarter of 2018.

Uzbekistan ranked 99 out of 160 countries in the Logistics Performance Index. This is evidenced by the report of the World Bank in the year of 2018. LPI (Logistics Performance Index) estimates the following six factors (in brackets shown the estimation for Uzbekistan):

1) the efficiency of the work of customs authorities( 2.10$)$;

2) the quality of the infrastructure (2.57);

3 ) simplicity in the organization of international supply of goods( 2.42$)$;

4) competence in logistics( 2.59 );

5) the ability to track the goods throughout the supply chain( 2.71 );

6) compliance with delivery deadlines( 3.09 ).

Experts drew attention to the need for accession to agreements and conventions in the field of transport, infrastructure and logistics. It should be mentioned that in November 2017 there was held International Conference called "Central Asia: One Past and a Common Future, Cooperation for 
Sustainable Development and Mutual Prosperity" in Samarkand, Uzbekistan. Where the president of the Republic of Uzbekistan Shavkat Mirziyoyev initiated the proposal of the UN General Assembly resolution "Strengthening regional and international cooperation to ensure peace, stability and sustainable development in the Central Asian region". The resolution places special emphasis on the development of transport infrastructure and transit corridors, on strengthening the interaction of all modes of transport, including the opening of new roads and railways, as well as air routes. That is why in September 2018, Tashkent became an international expert platform for developing ideas and proposals for the further development of transport projects in Central Asia: an international conference on "Central Asia in the System of International Transport Corridors: Strategic Perspectives and Unrealized Opportunities" was held in the capital. In the conference the perspectives of creation of a single international transport hub were discussed.

Conclusions. Uzbekistan is one of the fast developing countries in the world. Many modern successful states, building their own development models, spent hundreds of years developing the economy, the political and legislative system. Against this background, the successes achieved by Uzbekistan in just 27 years surprise or at least arouse the interest of the world community. The phenomenon of the "Uzbek development model" is recognized by experts and analysts of leading international financial institutions and research centers. For a historically short period of time, the country actively joined the process of international economic relations.

\section{REFERENCES}

1. "Development of logistics centers in Uzbekistan " , 2015. -2-3 pages Gulyamov Saidakhror Saidahmedovich, academician, doctor of economic sciences, professor, head of the department. Institute for Advanced Training of the State Statistics Committee of Uzbekistan; Shermukhamedov Abbas Tairovich doctor of Physical and Mathematical Sciences, professor. Tashkent Branch of the Russian Economic University named after G.V. Plekhanov

2. "Realities and prospects for the development of transport and logistics ", [31.01.2017]

3. "Logistics as an important link in the economy ", D. Mirzakhalilova [06.03.2013]

4. http://kommersant.uz/news/eksperty-obsudili-problemu-avtomobilnyh-gruzoperevozok-v-uzbekistane

5. https://lpi.worldbank.org/international/global?sort=desc\&order=LPI\%20Score\#datatable 